\title{
The Effect Of Play-Way Teaching Strategy On Primary School Pupils' Acquisition Of Basic Science Concepts
}

\author{
Victoria Ihekerenma Iroegbu PhD \\ Institute of Education \\ Obafemi Awolowo University, \\ Ile-Ife, Osun State, Nigeria
}

\begin{abstract}
This study investigated the effect of play-way teaching strategy on primary school pupils' acquisition of science concepts in the basic science and technology curriculum. The sample for the study consisted of sixty boys and girls in equal proportion that was randomized into three treatment groups. Stratified sampling technique was used in selecting equal number of boys and girls into the three groups. The treatment groups were free play group, teacher mediated play group and direct instruction groups with vicarious play activities. The treatment lasted three weeks for the groups who were pupils that successfully completed primary three at the end of the session. The content centered on basic ideas on water, floating and sinking, measures, simple machines and motion. A twenty item multiple choice objective test with reliability of 0.79 was used to determine learning outcomes. T-test analysis of group mean scores was used to evaluate the two hypotheses. Teacher structured play-way group obtained a mean score of 12.9 while direct instruction group obtained a mean score of 10.0. The obtained t-value of 4.061 is significant at $p<.05$. There was no gender effect among play-way pupils as boy and girls achieved mean scores of 12.1 and 12.2 respectively. The obtained $t$-value of 0.137 was not significant at five percent probability.
\end{abstract}

Keywords: play-way, teaching strategy, primary school, basic science, concepts, acquisition

\section{INTRODUCTION}

Science is one of the most important school subjects of the Basic Education Curriculum of the Nigerian educational system. The study of science exposes the learner to first hand encounter with natural phenomena, concepts, facts and procedures. Observations, recordings, discussions, explanations and elaboration on these are the essential recurrent requirements from a learner of science. Originally, the study of science was known as the study of nature. It is not surprising therefore that knowledge obtained from the study of science could be used to proffer solutions to numerous problems of life and living. It is for this reason that the study of science is popular among nations all over the world. However, numerous concepts of science are abstract and therefore difficult to comprehend and understand especially by young and inexperienced learners (Perkins \& Blythe, 1994; Adesoji, 2002). It is in this regard that researchers in instructional science advocate the use of hands-on and minds-on teaching strategies in teaching science to young learners (Iroegbu, 2000; Raimi and Adeoye 2002). The advantages of using these strategies include the fact that learners could recall the experiences of a hands-on activity long after the activity, whereas they would have forgotten the details of an activity which they learned through teacher talk during the same period. Learners also gain insight and a measure of satisfaction while doing hands-on activities more especially when performing experiments in science laboratories. 
Ivowi, Okebukola, Oludotun, and Akpan (1992) as well as Ukoh (2013) have reported a prolonged period of low achievement in Nigerian school science. As a consequence, many Nigerian students view science as a difficult subject and will therefore no longer want to study it. Probably the notion of science as a difficult subject might have promoted the drift away from science being observed lately in Nigerian education (Ukoh, 2013). Some researchers such as Adeyegbe (1993) had blamed the low achievement level on inefficient teaching methods adopted by the science teachers, such as teacher talking non-stop. Oguniyi (1986) had equally observed that monologue instructional condition encourages rote learning, which has been one of the recurring faults on Nigerian candidates in West African School Certificate Examinations (WAEC, 1985). Rote learning or memorization cannot be the strategy to be used for producing the scientists and engineers needed by Nigeria for social and economic development.

The nation requires sufficient numbers of well trained individuals with in-depth practical and conceptual knowledge in the domain of science to develop and sustain our economy, education, health services, agriculture and other facets of national development. There is therefore the pressing need to develop the teaching of basic sciences in Nigeria beyond the limits of rote learning, so that more youths will become interested in learning science once more. There is a possibility that the use of stimulating teaching strategies, such as hands-on activities, to teaching basic science concepts such as water, food, air, etc, to young children, may help learners' to develop interest and the quality of learning will consequently improve.

Many researchers have documented the fact that hands-on activities are among the best teaching strategies for learning practical and enduring science (Iroegbu, 2000; Eggen \& Kauchak, 2006). Play-way teaching strategy is a hands-on teaching strategy which young children enjoy all the time (Brewer, 2007). Perhaps it will be profitable to introduce science at the Basic level through the use of play-way activities, since science had been taught at the primary school level in the past using teacher dominated classroom presentation and had produced the current level of science underachievement among former products of the primary schools. It is imperative therefore that some other strategy that holds some promise should be tried.

Play is one of the major preoccupations of children. It is an activity which every child would like to engage in if left alone. It is a worthy activity through which a child explores the world around him/her and which enables the child to acquire some firsthand knowledge and experience about the natural world. Children are never bored with playing. In support if this assertion, Brewer (2007) described play as what young children spend most of their time doing which contributes to cognitive growth, aiding social and emotional development and is essential to physical development. Many of the abilities required to succeed in school setting are gained through play experience.

Early childhood educators have described and documented numerous examples of play that can be used for teaching pupils (Osayin, 2002). Some of the popular forms of play include the following: functional plays which involve the children in muscular activities; symbolic play, which is a form of play in which children pretend to be what they are not; games with rules, which are plays that help children to acquire discipline and principles; constructive plays involve children with erecting structures and models; fantasy plays, which are plays where children imagine unrealistic notions like fairy tales; cognitive plays which lead children to acquire some direct knowledge; outdoor plays, rough and tumble play, cooperative play etc. It is not possible to exhaust here the various types of play which engage the practice of young children. Among the types of play listed here, cognitive plays hold great promise for the study 
of science (Brewer, 2007). However, whatever play that children engage in leads them to the acquisition of some vital skill, or experience or knowledge or some of these.

Since play does not produce boredom in children, it is therefore appropriate to deploy play activity for teaching various facts and skills as well as concepts to children. Data from field studies have shown that children learn more from handling and experimenting with actual objects than they do from pictures, stories, video or from being told (Morrison, 2006).The scholar further revealed that when children are encouraged to manipulate and interact with the world around them, they begin to construct concepts about relationships, attributes and processes. It is important to realize that although these observations were made with children in the developed world, it is necessary to try out such experiments in the third world countries so that the experiences of children from the developing nations may also be documented. It is possible that children from the developing nations will benefit equally when provided with adequate play material including models of objects and real world items similar to those available to children in the developed nations.

Most primary school teachers in Nigeria are reluctant to teach science probably because they were not trained in most science subjects and therefore do not understand the meaning and nature of science. Adeyegbe (1993) had generalized the problem of poor acquisition of science concept, facts and principles to problems arising from inefficient method of teaching science employed by primary school teachers. It may be essential to state here the meaning of science with regards to the primary school curriculum. In this respect, science is both content and a process. It is the process of observing, thinking and reflecting on actions and events (Brewer, 2007).

In addition to this definition, other definitions exist; for instance Kilmer and Hoffman (1995) defined science as knowledge about specific phenomena (content), the process to collect and evaluate information (process or method of science) as well as the application of science to problems of human adaptation to the environment (technology). It is therefore not surprising that science is studied in the current curriculum as basic science and technology. Basic science and technology refers to the fundamental, simple and ordinary but common place observations and experiences on which science and technology are derived.

Deriving from science learning problems in Nigeria, some researchers have stated that science concepts in the Basic Science Curriculum are mostly observable phenomena, which can be described, explained, represented in models or diagrams or illustrated and demonstrated (Ivowi et al, 1992; Iroegbu and Okpala, 1997).The problem of misconception or lack of understanding in science that occur among Nigerian pupils are generally embedded in the employment of rote learning by both teachers and learners alike (Ogunniyi, 1986).The scholar had suggested that this problem could be overcome by adopting hands-on strategies that empower the learner to handle equipment, observe phenomena, record what was observed and discuss with peers (Iroegbu, 1998).This process is achievable through play-way activities at the basic level of education.

Although the teaching of basic science and technology is not popular at the primary and basic levels, the use of hands-on teaching strategies will hopefully reverse the trend. The strategy will assist the teachers and pupils to learn along together. Fagbemi (2002) had observed that primary school children achieve highly in agricultural science but poorly in other science subjects. The researcher attributed the observation to the practical way in which schools handle the study of agricultural science. What appears to be needed here for improved 
acquisition of science concepts, facts and principles is for teachers and pupils to resort to using practical approach, interwoven with principles of play while working through the curriculum requirement.

Science has been taught at the primary and basic levels like other non-science subjects by employing teacher dominated verbal classroom presentations. This method of instruction has been found in literature to be ineffective and unappealing to science students (Iroegbu, 1998) more especially at the basic level of education (Morrison, 2006). Since science must be taught at primary and basic levels, the useful methods of teaching that must be adopted must be those which have some appeal to the children to be taught.

It has been established that all children love to engage in play activities most of the period, when they are awake during the day (Brewer, 2007). There is the feeling that if play-way teaching strategy could be developed to teach some aspects of science at the primary and basic levels of education, the children's learning outcomes in science will improve. This study therefore investigated the effect of play-way teaching strategy on primary school children's acquisition of science related knowledge and skills.

\section{Objectives of the Study}

The objectives of this study are to:

i. Investigate the effect of play-way teaching strategy on primary school pupils' acquisition of basic science concepts.

ii. To examine the difference in the effect of play-way teaching strategy on pupils' acquisition of basic science concepts based on gender.

\section{Null Hypotheses}

i. There is no significant difference in the acquisition of basic science concepts by pupils exposed to different teaching strategies.

ii. There is no significant gender difference in the acquisition of basic science concepts by pupils.

\section{METHOD OF THE STUDY}

The study adopted a randomized equivalent - group design which is represented symbolically as:

$\begin{array}{lll}\mathrm{R} & \mathrm{X}_{1} & \mathrm{O}_{1} \\ \mathrm{R} & \mathrm{X}_{2} & \mathrm{O}_{2} \\ \mathrm{R} & \mathrm{X}_{3} & \mathrm{O}_{3}\end{array}$

Where R represents randomization of subjects unto experimental groups 1, 2 and 3 :

$\mathrm{X}_{1} \quad$ is the treatment given to group $\mathrm{A}$

$\mathrm{X}_{2} \quad$ is the treatment given to group $\mathrm{B}$

$\mathrm{X}_{3}$ is the placebo given to the control group, group $\mathrm{C}$

$\mathrm{O}_{1}, \mathrm{O}_{2}, \mathrm{O}_{3}$ are post-test observations for groups $\mathrm{A}, \mathrm{B}$ and $\mathrm{C}$ respectively.

Primary three pupils who were registered for summer school enrichment programme were the subjects of this study. Among them, thirty boys and thirty girls were randomized into three play groups with twenty pupils in each group. Thus the sample size for the study was sixty, with 20 pupils in each study condition. The play groups were characterized as follows: 


\section{Study Groups}

\section{Play Group X}

Play-way strategy: Here the play activities were learner motivated but with teacher supervision. The children in this group were allowed to select the type of activity that they would want to undertake with materials provided for them by the teacher and research assistants. The teacher and research assistant go around the small groups and ask pupils what they have noticed or learned through their play activities.

\section{Play Group $Y$}

Guided Play: In this group the teacher put out relevant materials to help the pupils reach determined goals. The teacher guided children on procedure and observations to make. The pupils proceed to their days' science play ground with their teacher and research assistant. The children then proceed to play with materials as guided by the teacher.

\section{Play Group Z}

Directed instruction strategy: In this group children play with materials following classroom rules or principles, as prescribed by the teacher. Individuals in the group proceeded step by step along the teacher's procedure, until the task was accomplished. The instructors and research assistant moderated activities in the class group according to the normal class time routine of the school.

The three groups were each exposed to nine periods of twenty minutes each of play activities and ten minutes each play day, of group discussion of activities. The tenth period was reserved for the post tests. Three different activity centers were selected for this study. These were

a) Activity centre with building blocks models and coloured shapes, rulers, tapes, scales and spring balances.

b) Activity centre with inclined planes, sea-saw, swings, skipping ropes, rotating wheels, analogue clocks.

c) Activity center with water baths, plastic bottles, funnels, plastic cups, water siphon, tag boats, pebbles, pieces of wood, ball bearing, cylinder bearings, plastic measuring cylinders and small plastic buckets. Every group had three periods of play activity at each of the three selected venues to enable each participant take part in play and make necessary observations.

\section{Instrument for data collection}

One instrument that was used for data collection was the "Primary Science Appreciation Test" (PSAT). The test was a 24 item objective test. Each item has a key and two distracters.

Originally the test has 36 items with 12 items drawn from each of the three areas covered by the participants. The final version of 24 items was equally weighed among the 3 areas with each venue contributing eight items. Each correct item was scored one mark while incorrect answer attracted zero score. Thus the maximum score was 24 marks, while the minimum score was zero marks.

In order to validate the instrument, the test was given to three early childhood education teachers with science training to vet for content and construct validity. Thereafter, the test was administered on 30 primary three school children in a different state. Their reaction to the test was taken into consideration in selection of items for use. The split half reliability was computed which yielded a reliability coefficient of 0.79 . This value was significant at .05 alpha levels. The result of the study was analyzed using analysis of variance technique. 


\section{RESULTS}

The result of this study is presented in section three.

The descriptive statistics of the sample for this study is presented in Table 1.

Table 1: Descriptive statistics the posttest achievement scores Dependent Variable: pupils test score

\begin{tabular}{|ll|r|r|r|}
\hline treatment group & gender of pupil & Mean & Std. Deviation & $\mathrm{N}$ \\
\hline free play & male & 13.6000 & 2.63312 & 10 \\
& female & 13.2000 & 3.19026 & 10 \\
& Total & 13.4000 & 2.85436 & 20 \\
& male & 13.0000 & 2.44949 & 10 \\
directed play & female & 11.4000 & 1.89737 & 10 \\
& Total & 12.2000 & 2.28496 & 20 \\
& male & 12.2000 & 3.04777 & 10 \\
conventional method & female & 11.2000 & 2.04396 & 10 \\
& Total & 11.7000 & 2.57723 & 20 \\
& male & 12.9333 & 2.69013 & 30 \\
& female & 11.9333 & 2.53164 & 30 \\
& Total & 12.4333 & 2.63848 & 60 \\
\hline
\end{tabular}

The data in Table 1 show that the treatment groups differed in their achievement mean scores, just like males and females. In order to explain these differences in mean scores, the data was subjected to the analyses of variance, using the pretest scores as covariate. 


\section{The analysis of variance is presented Table 2.}

Table 2: Analysis of variance of science achievement using pretest scores as covariate Dependent Variable: pupils test score

\begin{tabular}{|c|c|c|c|c|c|c|}
\hline \multicolumn{2}{|l|}{ Source } & $\begin{array}{c}\text { Type III Sum of } \\
\text { Squares }\end{array}$ & $\mathrm{df}$ & Mean Square & $\bar{F}$ & Sig. \\
\hline \multirow{2}{*}{ Intercept } & Hypothesis & 106.832 & 1 & 106.832 & 31.088 & .000 \\
\hline & Error & 75.109 & 21.856 & $3.436^{\mathrm{a}}$ & & \\
\hline \multirow{2}{*}{ Pretest } & Hypothesis & 202.623 & 1 & 202.623 & 67.550 & .000 \\
\hline & Error & 158.977 & 53 & $3.000^{\mathrm{b}}$ & & \\
\hline \multirow{2}{*}{ Trtgroups } & Hypothesis & 76.821 & 2 & 38.411 & 16.508 & .050 \\
\hline & Error & 4.993 & 2.146 & $2.327^{c}$ & & \\
\hline \multirow{2}{*}{ Gender } & Hypothesis & 9.950 & 1 & 9.950 & 4.310 & .174 \\
\hline & Error & 4.617 & 2.000 & $2.308^{\mathrm{d}}$ & & \\
\hline \multirow{2}{*}{ Trtgroup * gender } & Hypothesis & 4.617 & 2 & 2.308 & .770 & .468 \\
\hline & Error & 158.977 & 53 & $3.000^{\mathrm{b}}$ & & \\
\hline
\end{tabular}

a. .063 MS(gender) + .937 MS(Error)

b. MS(Error)

c. .973 MS(Trtgroup * gender) + .027 MS(Error)

d. 1.000 MS(Trtgroup * gender) + 6.324E-006 MS(Error)

Hypothesis I: There is no significant difference in the acquisition of basic science concepts by pupils exposed to different teaching strategies.

The answer to hypothesis I is contained in Table 2. The data in Table 2 show that the strategy of teaching was significant in this experiment $\left[\mathrm{F}_{(2,53)}=16.508 ; \mathrm{p}=.05\right]$.

Since the strategy of teaching was significant, it became necessary to determine the strategy that differed significantly from the others. For this reason, pair-wise comparison was performed for the strategies of instruction in Table 3. 
Table 3:Pair wise Comparisons of treatment groups' science mean achievement scores Dependent Variable: pupils test score

\begin{tabular}{|c|c|c|c|c|c|c|}
\hline \multirow[t]{2}{*}{ (I) treatment group } & \multirow[t]{2}{*}{ (J) treatment group } & \multirow{2}{*}{$\begin{array}{c}\text { Mean } \\
\text { Difference (I- } \\
\text { J) }\end{array}$} & \multirow[t]{2}{*}{ Std. Error } & \multirow[t]{2}{*}{ Sig. ${ }^{b}$} & \multicolumn{2}{|c|}{$\begin{array}{l}\text { 95\% Confidence } \\
\text { Interval for Difference }\end{array}$} \\
\hline & & & & & $\begin{array}{l}\text { Lower } \\
\text { Bound }\end{array}$ & $\begin{array}{l}\text { Upper } \\
\text { Bound }\end{array}$ \\
\hline \multirow{2}{*}{ free play } & directed play & $2.123^{*}$ & .559 & .000 & 1.001 & 3.244 \\
\hline & conventional method & $2.715^{*}$ & .561 & .000 & 1.589 & 3.841 \\
\hline \multirow{2}{*}{ directed play } & free play & $-2.123^{*}$ & .559 & .000 & -3.244 & -1.001 \\
\hline & conventional method & .592 & .548 & .285 & -.506 & 1.691 \\
\hline \multirow{2}{*}{ conventional method } & free play & $-2.715^{*}$ & .561 & .000 & -3.841 & -1.589 \\
\hline & directed play & -.592 & .548 & .285 & -1.691 & .506 \\
\hline
\end{tabular}

Based on estimated marginal means

*. The mean difference is significant at the .05 level.

Adjustment for multiple comparisons: Least Significant Difference (equivalent to no adjustments).

The data in Table 3 reveals that free play strategy (Mean score $=13.00$ ) was significantly better than directed play (Mean score $=12.200$ ), and significantly better than conventional strategy (Mean score $=11.700)$. The data show also that directed play strategy was also significantly better than conventional teaching strategy. The order of increasing teaching strategy effect is conventional strategy $<$ directed play strategy $<$ free play strategy.

\section{The effect of gender}

Hypothesis II: There is no significant gender difference in the acquisition of basic science concepts by pupils.

The result for the test of this hypothesis is contained in Table 2. The data in Table 2 show that the effect of gender was not significant in the achievement of pupils in science in this experiment: [F $(1,53)=4.310 ; \mathrm{p}>.05]$.

\section{DISCUSSION OF THE RESULTS}

The results in this experiment showed that play-way teaching strategy promoted higher level acquisition of science concepts in children than their usual teacher directed play often employed at this level of education. This finding is similar to those documented in Iroegbu (2011); Kieff et al (2000) and Morrison (2006). The result of the study also revealed that playway teaching strategy did not produce any gender (sex) difference in the acquisition of science concepts. The implication of this finding is that play-way teaching strategy could be used advantageously for the teaching of all children (male or female) without any adverse learning effect. Osayin (2002) had observed that play-way strategy could be used to keep children busy. But this experiment has shown that it can be even used to improve on science achievement, it is therefore a good teaching strategy.

\section{CONCLUSION}

In this era when children tend to neglect the study of science in preference to other disciplines, the use of play-way strategy during the early years of schooling will encourage more children to engage in the study of science. This is because children were eager to undertake their 
science play activities; sometimes they would choose to sacrifice their breaks in order to enjoy the activities further. The activity sessions were usually lively with children asking interesting questions. It is in this regard that this researcher believed that the play-way teaching strategy may be a useful weapon for improving young pupils' attitude to the study of basic science.

\section{RECOMMENDATIONS}

It is therefore recommended that further trials of this experiment should be carried out in other primary schools or basic level classes using other content areas in science. Play way teaching strategy should be employed for teaching rudimentary science at the early periods of primary school level. Teachers who may not be conversant with managing free play teaching strategy should try using directed play which produced similar effect with free play teaching strategy. The strategies may be used for both boys and girls separately or for mixed gender classes, since the strategies produced no gender effect.

\section{References}

Adesoji, F.A. (2002): Language crisis in the chemistry laboratory and its implication for curriculum development and implementation. Curriculum Development at the Turn of the Century: The Nigerian Experience. Ibadan: Department of Teacher Education, University of Ibadan.

Adeyegbe, S.O. (1993): The senior secondary school curriculum and candidates performance: An appraisal of the first cycle of operation. Journal of Science Teachers' Association of Nigeria, 28 (1 \& 2), 3-12.

Brewer, J.A. (2007): Introduction to Early Childhood Education Preschool through primary. Boston: Pearson Educational Inc.

Eggen, P.D. and Kauchak, D.P. (2006): Strategies and Models for Teachers: Teaching content and thinking skills. Boston. Person Education Inc.

Fagbemi, A.F. (2002): An Evaluation of some school Quality indicators on some primary schools in Ibadan North Local Government Area of Oyo State. Educational and Information studies Abstracts, 2000 - 2002; University of Ibadan.

Iroegbu, T.O. (1998). Effects of Problem -Based Learning, Numerical Ability and Gender as Determinant of Achievement, Problem solving and line graphing skills, in Senior Secondary physics in Ibadan. Unpublished thesis; University of Ibadan, Nigeria

Iroegbu, T.O. (2002). Exploring Hands-on investigations: Procedure and Paradigm from waves and optics; African Journal of Educational Research. 6 (1 \& 2), 51-56.

Iroegbu, T.0. (2011): Refocusing teaching and learning methods for high performance in science. A paper presented at the Lagos State training workshop for Mathematics, Physics and Technology teachers.

Iroegbu, T.O. and Okpala, P.N. (1997): Differences in Line-graphing skills of Nigerian Senior Secondary Physics students: A function of problem -based instruction, numerical ability and gender. Journal of Research in Science Education 2 (1): 49-55.

Ivowi, U.M.O., Okebukola, P.A.O. Oludotun, J.S.O. and Akpan, B.B. (1992): Raising the standard of performance Public examination in Science, Technology and Mathematics. Science Teachers Association of Nigeria: Position Paper 4.

Kieff, J and Casbergue, R. (2000): Playful Learning and Teaching: Integrating play into preschool and primary programs. Boston: Allyn \& Bacon

Kilmer, S.J. and Hofman, H. (1995): Transforming Science Curriculum in Reaching Potentials: Transforming Early Childhood Curriculum and Assessment. Vol. 2, 43-65.

Morrison, G.S. (2006): Fundamentals of Early Childhood Education: New Jersey Pearson Merril Prentice Hall.

Ogunniyi, M.B. (1986): Under-Achievement in Science and Emerging anti-science culture in Nigeria. Journal of STAN, 13 (1), 30-39.

Osayin, E.A. (2002): Early Childhood Education in Nigeria. Concept Publication Limited, Lagos.

Perkins, O. and Blythe, T. (1994): Putting understanding up front. Educational Leadership, 51 (5): 5-6. 
Raimi, S.M. and Adeoye, F.A. (2002): Gender difference among college students as determinants of performance in integration sciences African Journal of Science Education. 29 (9): 1043-1059.

Ukoh, E.U. (2012). Effects of Problem -based learning and interactive invention instructional strategies on NCE pre-service teachers' achievement in physics concepts and acquisition of science process skills. Unpublished Thesis, University of Ibadan, Nigeria

West African Examinations Council (WAEC) (1985) Chief Examiners Report: May-June (0/L), Science Subjects, 938. 